\title{
Effect of Plant Geometry and Weed Management on Nutrient Uptake and Economics of Summer Mungbean (Vigna radiata L.)
}

\author{
Randhir Kumar, Kaushal Kishor*, Bharati Upadhaya, \\ Prabhat Kumar and Rahul Kumar Raushan
}

\author{
Department of Agronomy, Dr. Rajendra Prasad Central Agricultural University, \\ Pusa, Samastipur, Bihar, India \\ *Corresponding author
}

\section{A B S T R A C T}

A field experiment was carried out during summer season of 2017 at research farm of TCA Dholi, Dr. Rajendra Prasad Central Agricultural University, Pusa, Samastipur (Bihar) to study the "Effect of plant geometry and weed management

\section{Keywords}

Mungbean, Plant Geometry, Weed Management Practices, Nutrient Uptake, Economics

Article Info

\section{Accepted:}

25 December 2019 Available Online: 20 January 2020 on nutrient uptake and economics of summer mungbean (Vigna radiata L.)" The experiment was laid out in randomized block design with three replications. The treatment comprised of three plant geometry i.e., $20 \mathrm{~cm} \times 10 \mathrm{~cm}, 25 \mathrm{~cm} \times 10 \mathrm{~cm}$ and $30 \mathrm{cmx} 10 \mathrm{~cm}$ and five weed management practices i.e., weedy check, hand weeding at 15 and 30 DAS, Pendimethalin @ $0.75 \mathrm{~kg} / \mathrm{ha}$ (pre-emergence), Quizalofop-ethyl @60 g/ha at 15 DAS and Imazethapyr @ 60 g/ha at 15 DAS. Significantly higher NPK-uptake by the crop was recorded under closer row spacing of $20 \mathrm{~cm} \times 10 \mathrm{~cm}$ than wider row spacings. Similarly, hand weeding twice recorded significantly higher NPK uptake by crop and lowered NPK-depletion by weeds than chemical weeding except K- uptake. Closer row spacing of $20 \mathrm{~cm} \times 10$ $\mathrm{cm}$ recorded significantly higher gross returns, net returns and $\mathrm{B}$ : $\mathrm{C}$ ratio than wider row spacing of $25 \mathrm{~cm} \times 10 \mathrm{~cm}$ and $30 \mathrm{~cm} \times 10 \mathrm{~cm}$. Among the weed management practices, hand weeding twice recorded significantly higher gross returns while the highest net return and $\mathrm{B}$ : $\mathrm{C}$ ratio were associated with Imazethapyr.

\section{Introduction}

Among the pulses, green gram (Vigna radiata L.) is one of the most important and extensively cultivated crops in India. It contains about $25 \%$ protein, $1.3 \%$ fat, $3.5 \%$ mineral, $4.1 \%$ fiber and $56.7 \%$ carbohydrate. Inspite of the importance of this crop in our daily diet, average productivity of this crop is very low in India. The low production of this crop is mainly due to lack of ideal plant geometry, crop-weed competition and other reasons. Plant geometry plays an important role in the dominance and suppression of weeds during the process of competition. Ideal plant geometry is precious and 
important for better and efficient utilization of available plant growth resources in order to get maximum productivity in crops. Weed management is an important key factor for enhancing the productivity of green gram, as weeds compete for nutrient, water, light and space with crop plants during early growth period. Depending on weed type and crop weed competition it reduces crop yield up to 96.5\% (Verma et al., 2015), whereas the loss of green gram yield due to weeds ranges from 65.4 to $79.0 \%$ (Dungarwal et al., 2003). The magnitude of losses largely depends upon the composition of weed flora, period of weedcrop competition and its intensity. Hand weeding is generally adopted for the weed control in green gram, but it is laborious, time consuming, costly and tedious. With increase in labour cost and constraints in availability on time, manual weed control is no more an economical in mung bean. There was an urgent need to sort out a broad-spectrum efficient post-emergence herbicide including Quizalofop-ethyl and Imazethapyr for effective control of weeds in summer greengram to optimize productivity, Considering these points in view, the present investigation was done for selection of ideal plant geometry and chemical weed management practices for higher grain yield.

\section{Materials and Methods}

The field experiment was conducted during summer season of 2017 at research farm of Tirhut College of Agriculture Farm, Dholi, Dr. Rajendra Parsad Central Agricultural University, Pusa (Samastipur) Bihar. The soil of the experimental plot was low in organic carbon, available nitrogen, available $\mathrm{P}_{2} \mathrm{O}_{5}$ and medium in available $\mathrm{K}_{2} \mathrm{O}$ which indicate that the soil was low in fertility status. The treatment consists of three plant geometry i.e., $20 \mathrm{~cm} \times 10 \mathrm{~cm}, 25 \mathrm{~cm} \times 10 \mathrm{~cm}$ and $30 \mathrm{~cm} \mathrm{x}$ $10 \mathrm{~cm}$ and five weed management practices i.e., weedy check, hand weeding at 15 and 30 DAS, Pendimethalin @ $0.75 \mathrm{~kg} / \mathrm{ha}$ (pre- emergence), Quizalofop-ethyl @ 60 g/ha at 15 DAS and Imazethapyr @ 60 g/ha at 15 DAS. The experiment was laid out in randomized block design and replicated thrice. A plot having uniform fertility and even topography was selected for experimental trial. A pre-sowing irrigation was given before field preparation to obtained proper germination and establishment of the crop. Mung bean variety 'HUM 16' was sown in the summer season of 2017 using the seed rate of $25 \mathrm{~kg} / \mathrm{ha}$. Seed was treated with fungicide, Thiram @ $2 \mathrm{~g} / \mathrm{kg}$ of seed before sowing against fungal diseases. Plant to plant distance of $10 \mathrm{~cm}$ was maintained by thinning after 15 days of sowing. One irrigation was given at 20 DAS to the crop. The recommended dose of fertilizer (20:40:0 kg $\mathrm{N}: \mathrm{P}_{2} \mathrm{O}_{5}: \mathrm{K}_{2} \mathrm{O} /$ ha) was applied. Pendimethailn was applied on next day of sowing while Imazethapyr and Quizalofop ethyl were applied at 15 days after sowing. These herbicides were sprayed with knapsack sprayer fitted with flat fan nozzle using 600 litres of water per hectare. Hand weeding operations was performed at 15 and 30 DAS. Two pickings were done by hand for complete harvest of mature pod per plot. The weight of grains and straw were recorded treatment wise and converted into quintal per hectare.

\section{NPK content in $\operatorname{crop}(\%)$}

The plant samples after recording dry matter were grind and collected in a butter paper bag and later used for chemical analysis. The amount of nitrogen was estimated by method described by Jackson (1967) and expressed in percentage. Phosphorus content in plant was determined by vanadomolybdophosphoric yellow colour method (Jackson, 1967) by using spectrophotometer at $420 \mathrm{~nm}$ and expressed the concentration in percentage. Potassium content in plant parts was estimated by using Flame photometer (Jackson, 1967) and expressed in percentage. 
Total uptake of nitrogen, phosphorus and potassium were calculated for each treatment separately using the following formula -

Nutrient uptake $(\mathrm{kg} / \mathrm{ha})=\frac{\% \text { Nutrient concentration x Biomass }(\mathrm{kg} / \mathrm{ha})}{100}$

\section{Chemical analysis of soil samples}

Composite soil sample from 0-30 $\mathrm{cm}$ depth was collected from each plot before sowing and after harvest of mungbean for estimation of available nitrogen, phosphorus and potassium. Organic carbon present in the soil was determined by Walkley and Black (1934) method as described by Jackson (1973).Available soil nitrogen was estimated by alkaline permanganate oxidation method as outlined by Subbaiah and Asija (1956).

Available phosphorus content of soil samples was estimated by Olsen's method (Jackson, 1967).

Available potassium of soil samples was determined in 1:5 ammonium acetate extract of the soil using flame photometer (Jackson, 1967).

\section{Economics}

Economic indices were worked out based on the prevailing market prices in each case. Cost of cultivation was worked out by taking into consideration all the expenses incurred in raising the crop.

Total gross return (₹/ha) was worked out by multiplying the yield (grain+straw) per hectare under various treatments with prevailing market rate.

Net return(₹/ha) was obtained by subtracting the cost of cultivation from gross return of the individual treatments.
Benefit: Cost ratio was calculated by the following formula.

Benefit : Cost ratio $=\frac{\text { Net } \operatorname{profit}(\mathrm{Rs} / \mathrm{ha})}{\text { cost of cultivation }(\mathrm{Rs} / \mathrm{ha})}$

\section{Results and Discussion}

Effect of plant geometry and weed management on total $N, P$ and $K$ uptake by the crop N, P, K uptake by the crop (kg/ha)

A keen observation of mean data on $\mathrm{N}, \mathrm{P}, \mathrm{K}$ uptake by the crop revealed that $\mathrm{N}, \mathrm{P}, \mathrm{K}$ uptake by the crop decrease with increase the row spacing. Closer plant geometry of 20 $\mathrm{cm} \times 10 \mathrm{~cm}$ recorded significantly higher $\mathrm{N}, \mathrm{P}$, $\mathrm{K}$ uptake (99.47, 11.46 and 164.08) which significantly decrease with increasing the row spacing and recoded significantly lowered N,P,K uptake by row spacing of $30 \mathrm{~cm} \times 10$ $\mathrm{cm}$. Weed management practices significantly increase $\mathrm{N}, \mathrm{P}, \mathrm{K}$ uptake by the crop than weedy check $(59.94,6.10,99.20)$. Among the weed control treatments, significantly higher N,P,K uptake was recorded in hand weeded plot (111.96, 13.59, 183.35) than chemical weeding except $\mathrm{K}$ uptake. The $\mathrm{K}$ uptake recoded under hand weeding and Imazethaypr was at par. Among the herbicidal treatments, Imazethaypr recorded significantly higher N,P,K uptake by the crop than Quizalofop ethyl (95.12, 11.00, 159.42) and Pendimethalin. Similarly, Quizalofop ethyl also significantly surpassed over Pendimethalin.

Nutrient uptake by crop is a function of their concentration and dry matter production of plants. The higher NPK uptake by crop in weed free condition may be due to decreased crop-weed competition has concurrently increased nutrient availability better crop growth and higher crop biomass production coupled with more nutrient content. 
Effect of plant geometry and weed management on economics

\section{Gross returns (₹ /ha)}

A close perusal of data indicated that the highest gross returns was obtained at closest row spacing of $20 \mathrm{cmx} 10 \mathrm{~cm}$ (₹ 76,226/ha) which was significantly higher over wider row spacing of $25 \mathrm{cmx} 10 \mathrm{~cm}$ (₹ 68224/ha) and $30 \mathrm{~cm} \times 10 \mathrm{~cm}$ (₹ 56067/ha). The data pertaining to gross returns under the influence of weed management treatments indicate that all the treatments recorded significant higher gross return than weedy check ( $₹ 44295 /$ ha). The data further clarify that hand weeding twice resulted the maximum gross returns (₹ 84,367/ha) which was found significantly higher over chemical weeding. Gross return also varied significantly among the herbicidal treatments. Among the herbicidal treatments, maximum gross return was recorded under Imazethapyr (₹ 78,839/ha) while minimum was noticed under Pendimethalin (₹ 55755/ha).

Net returns (₹ /ha)

Net returns varied significantly due to planting geometry. The highest net returns was obtained from the closer row spacing 20 $\mathrm{cm} \times 10 \mathrm{~cm}$ (₹ 46591/ha) which was significantly higher over wider spacing of 25 $\mathrm{cm} \times 10 \mathrm{~cm}$ (₹ $38589 / \mathrm{ha}$ ) and $30 \mathrm{~cm} \mathrm{x} 10 \mathrm{~cm}$ (₹ 26432/ha). Row spacing of $25 \mathrm{~cm} \times 10 \mathrm{~cm}$ also recoded significantly higher net return than $30 \mathrm{~cm} \times 10 \mathrm{~cm}$.

The data pertaining to net returns under the influence of weed management treatments indicate that weed control treatment significant enhanced net return than weedy check (₹ 18294/ha). Among the weed control treatments, Imazethapyr (₹ 51503/ha) which was higher over Quizalofop ethyl (₹ 42164/ha) and Pendimethalin (₹ 28014/ha). Quizalofop ethyl also significantly enhanced net return over Pendimethalin.

Table.1 Effect of plant geometry and weed management on N, P and K uptake by the crop

\begin{tabular}{|c|c|c|c|}
\hline \multirow[t]{2}{*}{ Treatment } & \multicolumn{3}{|c|}{ Total nutrient uptake $(\mathrm{kg} / \mathrm{ha})$} \\
\hline & $\mathbf{N}$ & $\mathbf{P}$ & $\mathbf{K}$ \\
\hline \multicolumn{4}{|l|}{ Plant geometry } \\
\hline $20 \mathrm{~cm} \times 10 \mathrm{~cm}$ & 99.47 & 11.46 & 164.08 \\
\hline $25 \mathrm{~cm} \times 10 \mathrm{~cm}$ & 91.36 & 10.57 & 151.82 \\
\hline $30 \mathrm{~cm} \times 10 \mathrm{~cm}$ & 77.36 & 8.89 & 130.03 \\
\hline SEm \pm & 2.54 & 0.21 & 2.98 \\
\hline $\mathrm{CD}(\mathrm{P}=\mathbf{0 . 0 5})$ & 5.28 & 0.62 & 8.68 \\
\hline \multicolumn{4}{|l|}{ Weed Management } \\
\hline Weedy check & 59.94 & 6.103 & 99.203 \\
\hline Hand Weeding at 15 and 30 DAS & 111.96 & 13.59 & 183.35 \\
\hline Pendimethalin @0.75 kg/ha at pre-emergence & 75.27 & 8.48 & 127.03 \\
\hline Quizalofop-ethyl @60 g /ha (15 DAS) & 95.12 & 11.00 & 159.42 \\
\hline Imazethapyr @ 60 g /ha (15 DAS) & 104.77 & 12.41 & 174.21 \\
\hline SEm \pm & 2.32 & 0.27 & 3.85 \\
\hline $\mathrm{CD}(\mathbf{P}=\mathbf{0 . 0 5})$ & 6.75 & 0.79 & 11.21 \\
\hline
\end{tabular}


Table.2 Effect of plant geometry and weed management on economics of summer mungbean

\begin{tabular}{|c|c|c|c|}
\hline Treatment & $\begin{array}{c}\text { Gross return (Rs } \\
\left.\text { ha }^{-1}\right)\end{array}$ & $\begin{array}{l}\text { Net return } \\
\left(\text { Rsha }^{-1}\right)\end{array}$ & $\begin{array}{l}\text { Benefit : Cost } \\
\quad \text { ratio }\end{array}$ \\
\hline \multicolumn{4}{|l|}{ Plant geometry } \\
\hline $20 \mathrm{~cm} \times 10 \mathrm{~cm}$ & 76226 & 46591 & 1.57 \\
\hline $25 \mathrm{~cm} \times 10 \mathrm{~cm}$ & 68224 & 38589 & 1.30 \\
\hline $30 \mathrm{~cm} \times 10 \mathrm{~cm}$ & 56067 & 26432 & 0.89 \\
\hline SEm \pm & 2079 & 1246 & 0.028 \\
\hline $\mathrm{CD}(\mathrm{P}=\mathbf{0 . 0 5})$ & 6054 & 3629 & 0.083 \\
\hline \multicolumn{4}{|l|}{ Weed Management } \\
\hline Weedy check & 44295 & 18294 & 0.71 \\
\hline Hand Weeding at 15 and 30 DAS & 84367 & 46047 & 1.20 \\
\hline $\begin{array}{l}\text { Pendimethalin@0.75 kg /ha at pre- } \\
\text { emergence }\end{array}$ & 55755 & 28014 & 1.01 \\
\hline Quizalofop-ethyl @ 60 g /ha (15 DAS) & 70939 & 42164 & 1.46 \\
\hline Imazethapyr @60 g /ha (15 DAS) & 78839 & 51503 & 1.88 \\
\hline SEm \pm & 2684 & 1609 & 0.04 \\
\hline $\mathrm{CD}(\mathrm{P}=\mathbf{0 . 0 5})$ & 7816 & 4685 & 0.11 \\
\hline
\end{tabular}

Table.3 Effect of plant geometry and weed management on grain yield, straw yield of summer mungbean

\begin{tabular}{|c|c|c|}
\hline Treatment & Grain yield (q/ha) & Straw yield (q/ha) \\
\hline \multicolumn{3}{|l|}{ Plant geometry } \\
\hline $20 \mathrm{~cm} \times 10 \mathrm{~cm}$ & 12.53 & 22.23 \\
\hline $25 \mathrm{~cm} \times 10 \mathrm{~cm}$ & 11.19 & 20.17 \\
\hline $30 \mathrm{~cm} \times 10 \mathrm{~cm}$ & 9.17 & 16.99 \\
\hline SEm \pm & 0.26 & 0.60 \\
\hline $\mathrm{CD}(\mathrm{P}=\mathbf{0 . 0 5})$ & 0.77 & 1.77 \\
\hline \multicolumn{3}{|l|}{ Weed Management } \\
\hline Weedy check & 7.19 & 14.05 \\
\hline Hand Weeding at 15 and 30 & 13.92 & 23.87 \\
\hline DAS & & \\
\hline $\begin{array}{l}\text { Pendimethalin@ } 0.75 \mathrm{~kg} / \mathrm{ha} \\
\text { at pre-emergence }\end{array}$ & 9.10 & 17.08 \\
\hline $\begin{array}{l}\text { Quizalofop-ethyl @ } 60 \text { g /ha } \\
\text { (15 DAS) }\end{array}$ & 11.62 & 21.15 \\
\hline $\begin{array}{l}\text { Imazethapyr @60 g /ha (15 } \\
\text { DAS) }\end{array}$ & 12.97 & 22.83 \\
\hline SEm \pm & 0.34 & 0.78 \\
\hline $\mathrm{CD}(\mathrm{P}=\mathbf{0 . 0 5})$ & 0.99 & 2.28 \\
\hline
\end{tabular}


Fig.1 Effect of plant geometry and weed management on N, P and K uptake by the crop

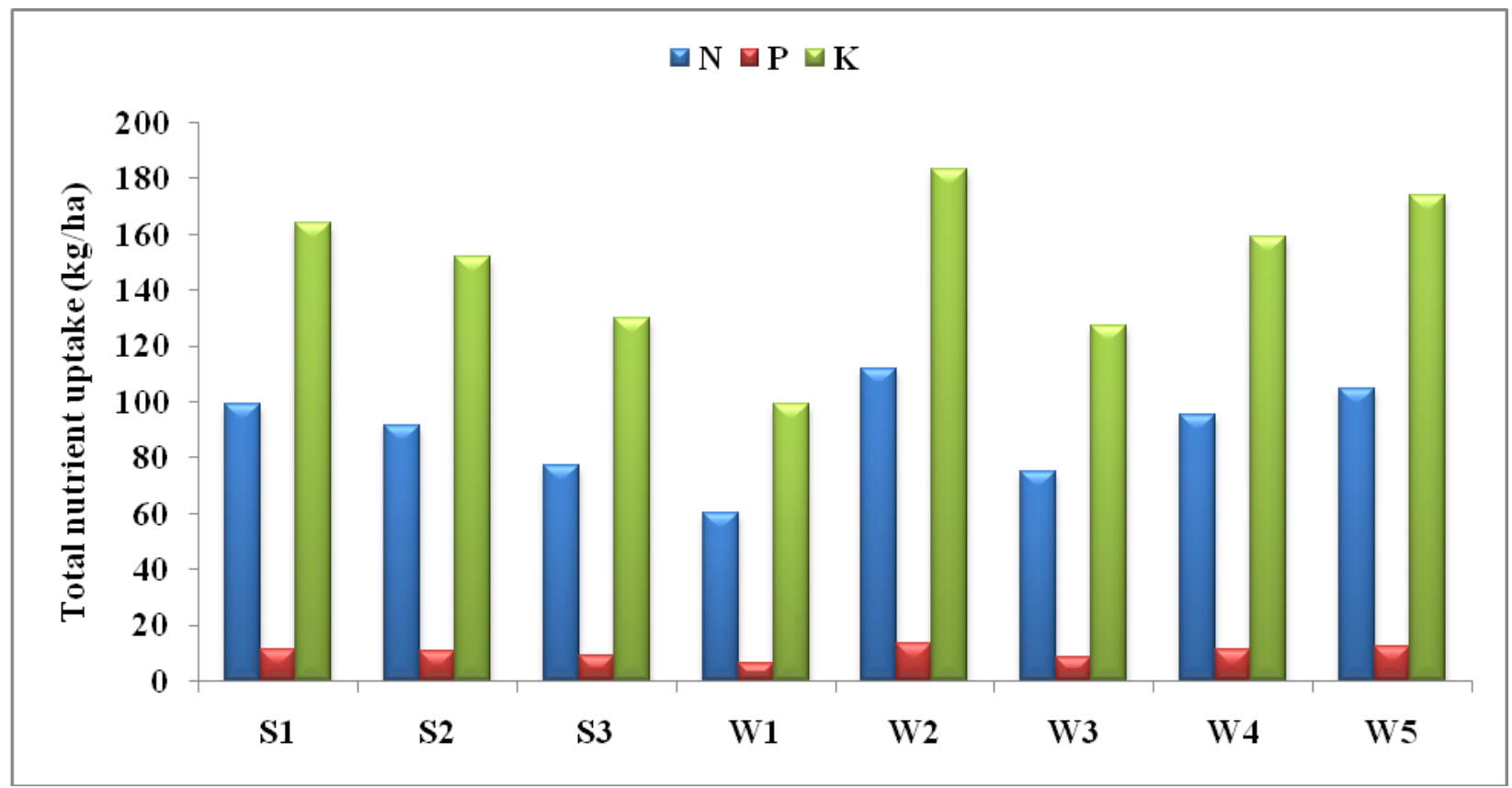

Fig.2 Effect of plant geometry and weed management on economics of summer mungbean

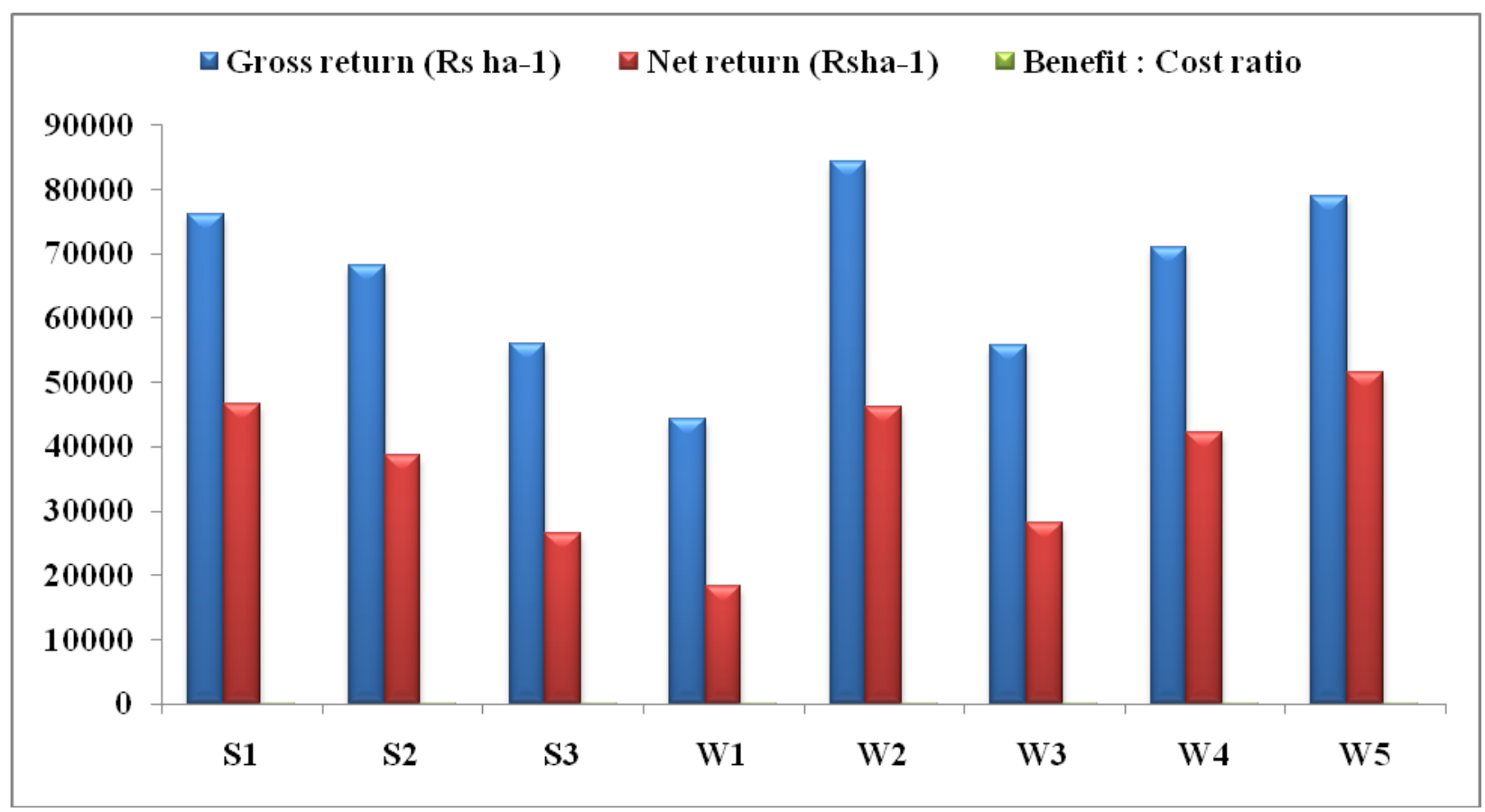

\section{Benefit: cost ratio}

A close scrutiny of data indicated that benefit: cost ratio varied significantly among planting geometry. The highest benefit: cost ratio was obtained under the closer row spacing of 20 $\mathrm{cm} \times 10 \mathrm{~cm}$ (1.57) which was significantly higher over wider spacing of $25 \mathrm{cmx} 10 \mathrm{~cm}$ (1.30) and $30 \mathrm{~cm} \times 10 \mathrm{~cm}(0.89)$. The row 
spacing of $25 \mathrm{~cm} \times 10 \mathrm{~cm}$ also significantly surpassed over $30 \mathrm{~cm} \times 10 \mathrm{~cm}$. The data pertaining to benefit: cost ratio under the influence of weed management practices indicated that weed control treatments brought significant high B: C ratio over weedy check (0.71). Among the weed control treatments, Imazethapyr recorded significantly highe $\mathrm{B}$ : $\mathrm{C}$ ratio (1.88) than Quizalofop ethyl (1.46), hand weeding and Pendimethalin. Similarly, Quizalofop ethyl also enhanced $\mathrm{B}: \mathrm{C}$ ratio than hand weeding and Pendimethalin.

The higher gross return in hand weeding might be due to more yield of grain and straw. But the involvement of more labours for removal of weeds and their higher wages, the cost of cultivation was increased many fold in this treatment which cause drastic reduction in net return and $\mathrm{B}: \mathrm{C}$ ratio. The involvement of lower cost in Imazethapyr on other hand enhanced net return and $\mathrm{B}$ : $\mathrm{C}$ ratio. This finding is in conformity with the result of Singh et al., (2001) and Rathi et al., (2004).

From the experiment It was concluded that closet plant spacing of $20 \mathrm{~cm} \times 10 \mathrm{~cm}$ found significantly higher gross return, net return, $\mathrm{B}$ : $\mathrm{C}$ ratio and nutrient uptake than wider plant spacings.

Among the weed control treatment, Imazethapyr recorded highest net return and B: $\mathrm{C}$ ratio than other weed control treatments. However, significantly higher nitrogen, phosphorous and potassium uptake by the crop was recorded under hand weeding than chemical weeding except $\mathrm{K}$ uptake, where it was at par with Imazethaypr.

\section{References}

Dungarwal, H. S., Chalot, P. C. and Nagda, B. L. 2003. Chemical weed control in mungbean (Pheseolus radiates L.). Indian Journal of Weed Science. 35(34): 283- 284.

Jackson, M. L.1973. Soil Chemical Analysis. Prentice Hall of India Pvt. Ltd., New Delhi.

Rathi, J.P.S., Tiwari, A.N. and Kumar, M. 2004. Integrated weed management in blackgram (Vigna mungo). Indian Journal of Weed Science 36(3\&4): 218 220.

Singh, R.C., Singh, M. and Kumar, R. 2001. Response of mungbean (Vigna radiata) to phosphorus application with and without FYM and $\mathrm{ZnSO}_{4}$. Haryana Agricultural University Journal of Research 31(3\&4): 89-92.

Subbiah, B.V. and Asija, G.L. 1956. A rapid procedure for the estimation of available nitrogen in soils. Current Science 25: 259-260.

Verma, S. K., Singh, S. B., Meena, R. N., Prasad, S. K., Meena, R. S. and Gaurav. 2015. A review of weed management in India: the need of new directions for sustainable agriculture. The Bioscan. 10(1): 253-263.

Walkley, A. and Black, I.A. 1934. Estimation of soil organic carbon by the chromic acid titration method. Soil Science. 37: 29-38.

\section{How to cite this article:}

Randhir Kumar, Kaushal Kishor, Bharati Upadhaya, Prabhat Kumar and Rahul Kumar Raushan. 2020. Effect of Plant Geometry and Weed Management on Nutrient Uptake and Economics of Summer Mungbean (Vigna radiata L.). Int.J.Curr.Microbiol.App.Sci. 9(01): 2663-2669. doi: https://doi.org/10.20546/ijcmas.2020.901.302 